\title{
微小流路を移動する細胞の検出機構実装法
}

\author{
藤 本 香 織*1 國 松 禎 明*2 前 泰 志*3 田 窪 朋 仁*3 \\ 新 井健 生*3 井上健 司*4 山田真 人*5
}

\section{Implementation of Cell Detection Mechanism on Microfluidic Chip}

\author{
Kaori Fujimoto*1, Sadaaki Kunimatsu*2, Yasushi Mae ${ }^{* 3}$, Tomohito Takubo*3, \\ Tatsuo Arai ${ }^{* 3}$, Kenji Inoue ${ }^{* 4}$ and Masato Yamada*5
}

\begin{abstract}
The paper describes development of a compact and economical sensing system to detect a cell in a micro channel which can be integrated easily on a micro PDMS (polydimethylsiloxane) chip. The light-intersecting method is adopted for detecting a cell moving in the channel, since the mechanism can be basically composed of only a light source element and a detector. The paper proposes an integrating procedure and shows the experiment in order to bear out feasibility of the system. Furthermore, a method of implementation of the mechamism on a micro PDMS chip is described.
\end{abstract}

Key Words: Cell Detection, Microfluidic Chip, Light-intersecting Method

\section{1. 緒言}

核移植技術は，再生医療や創薬などの広範な分野への高い有 用性から脚光を浴びている。しかし，現状では熟練技術者の顕 微鏡下での手作業により実現されており，作業に多くの時間を 必要とするため生産性が極めて低い。その上，手作業による操 作では人手を増強する以外に生産性を高める手段がなく，今後 ますます伸びると予想される需要に対して供給を確保する手段 が必要となる，近年，核移植作業を自動化することで供給の増 加を目指した「マイクロロボティクスを適用した胚操作の自動 化」というプロジェクトが推進されている [1].このプロジェク トでは卵子の切断・分離・カップリング・融合などの操作を基板 上に構成した微小流路やウェル内で実現することを想定してい る.そのため, 基板が独立してモジュール化されており，細胞に 対して何らかの操作を加えるためには，少なくともモジュール 内およびモジュール間において細胞を検出する必要がある。し

原稿受付 2007 年 11 月 16 日

*1シャープ株式会社

*2熊本大学

*3 大阪大学

${ }^{* 4}$ 山形大学

*5三洋電機株式会社

${ }^{* 1}$ SHARP Corporation

*2 Kumamoto University

*3 Osaka University

${ }^{* 4}$ Yamagata University

${ }^{* 5}$ SANYO Electric Co., Ltd.

口本論文は有用性で評価されました。
かし，従来は技術者が顕微鏡を用いて目視による検出を行って いたこと，およびこのような用途を想定したセンサに需要がな かったために，核移植技術において細胞を自動検出するセンサ は開発されていない.

一方, 従来提案されている液体中の粒子を測定するセンサは, 粒子数, 粒子径, 粒子形状, 粒度分布等の測定を目的として開 発されている. 測定原理として主に光散乱法 [2], 光遮断法 [3], 電気抵抗法等が知られている。しかし, 従来開発されているも のはいずれも大型もしくは中型で，とても小型とは言い難い. その理由として, それ単体で様々な測定を完結する装置として 提案されており，他の機器の一部として組み込むようなセンサ 機能としての役割を果たすようには開発されておらず，純粋な センサとして用いるには小型なものが必要となる. 本研究で提 案するセンサは機能を限定することで，七ンサの装着部分の面 積を $1\left[\mathrm{~cm}^{2}\right]$ 未満に小型化したものである。また，従来は粒子 の性質や特徵を定性的，定量的に測定することを目的として開 発されており，測定後の粒子に関することは一切考慮されてい なかった．しかし，本研究では生きた細胞を扱うことを前提と しており，測定後に細胞が生存していることが絶対条件となる. したがって, 素材と細胞との親和性および衛生面からのディス ポーザブル性が要求されるが，従来ではこのような要望が必要 とされていなかったため, 従来の機器ではこれについてもまっ たく考慮されていない.

そこで本研究では, 計測後も細胞が生存可能であることを前 提に，モジュール基板に組み込み可能であり，モジュール基板 上に構成された微小流路内を移動する細胞を検出するセンサを 
開発することを目的とする。

\section{2. センサの基本構成}

\section{1 要求仕様}

本研究で求められる細胞検出センサの仕様として, 下記の 6 項目を設定している.

（1）微小流路を流れる細胞を確実に検出可能

（2）計測細胞サイズを数〜数百 $[\mu \mathrm{m}]$ サイズまで自在に変更可能

(3) 全長数 $[\mathrm{cm}]$ 未満の小型サイズ設計

（4）顕微鏡などの特別な装置が不要な取り付け機構

（5）ディスポーザル性㧍よび細胞との親和性

（6）特別な素材，機器等を用いることなく安価に製造可能

上記 6 項目の各詳細を説明する. (1) 流路を流れる細胞を確実 に検出可能であることは基本である.（2）細胞にも種々の大き さがあり，核のサイズである数 $[\mu \mathrm{m}]$ から細胞本体のサイズで ある数百 $[\mu \mathrm{m}]$ を想定しているため，この範囲内のどの大きさ でもあっても検出可能となるように対応させる. (3) 本センサ を搭載する予定の基板自体が小型であるため, 全長数 $[\mathrm{cm}]$ 未満 にする必要がある。（4）モジュール基板に取り付けることを想 定しているため, 特別な機器を用いることなく容易に取り付け られる必要がある。(5) 生きた細胞を取り扱うことを前提とし ているため, 清潔さを求めるためにディスポーザルであること が要求されるとともに, 材料には当然細胞との親和性も要求さ 机る。(6) ディスポーザル性を要求しているため, 安価である ことも要求される。

基本となる流路形成の材料として, 成型加工が容易なシリコ ンゴムの一種であるPDMS (polydimethylsiloxane) を用いる. 流路の作成方法として, ソフトリソグラフィ [4]〜 [7]により作製 する. 本論文で計測対象とする細胞のサイズは約 $80 \sim 100[\mu \mathrm{m}]$ とし, 細胞の移動速度は $1,000[\mu \mathrm{m} / \mathrm{s}]$ 以下で確実に検出できる ことを目標とする。流路のサイズは対象細胞の 2 倍のサイズで ある幅 $200[\mu \mathrm{m}]$, 深さ $200[\mu \mathrm{m}]$ 以下とした。また, PDMS は 細胞との親和性が良く, 流路作成のためのカバーとして用いる ガラスも親和性が良く, 両素材とも安価であることから，ディ スポーザルにも適している。

\section{2 検出法の選定}

本研究の目的・要求仕様は 2.1 節で述べたとおり, PDMS で 作製した微小流路内を移動する細胞を確実に検出し, その検出 機構をPDMS チップに実装することである，直径 $100[\mu \mathrm{m}]$ 以 下の細胞を対象とするので検出法は細胞検出に十分な感度が必 要であるが, 検出機構が小型化・チップへの実装が容易な検出 法でなければならない. 検出法の特徵を Table 1 に示す。感度 の点では, 光散乱法や電気抵抗法が優位であるが, これらの検 出機構は非常に複雑で, 小型化が困難であると思われる。また, これらの点やコストの点を踏まえ, 本研究では光遮断法を検出 法として選択した，光遮断法で細胞を確実に細胞を検出するた めには, Fig. 1(a)のように照射光が流路の幅に合わせて過不 足なく当たることが要求される. Fig. 1 (b)の上うに流路幅・細 胞より照射光が細い場合, 流路を完全に覆うことができず, 細 胞の通過を検知できない場合がある. Fig. 1 (c) のように照射光
Table 1 Measurement methods of minute particles

\begin{tabular}{|l|l|c|c|c|c|}
\hline method & $\begin{array}{l}\text { detection } \\
\text { mechamism }\end{array}$ & $\begin{array}{c}\text { sensi- } \\
\text { tivity }\end{array}$ & $\begin{array}{c}\text { miniatu- } \\
\text { rization }\end{array}$ & cost & $\begin{array}{c}\text { imple- } \\
\text { mentation }\end{array}$ \\
\hline $\begin{array}{l}\text { light } \\
\text { intersecting }\end{array}$ & $\begin{array}{l}\text { light source } \\
\text { light receiving } \\
\text { element }\end{array}$ & $\Delta$ & 0 & $\bigcirc$ & 0 \\
\hline $\begin{array}{l}\text { light } \\
\text { scattering }\end{array}$ & $\begin{array}{l}\text { light source, } \\
\text { light-sensitive } \\
\text { tube } \\
\text { light strap, } \\
\text { gobo, etc. }\end{array}$ & $\bigcirc$ & $\Delta$ & $\Delta$ & $\times$ \\
\hline $\begin{array}{l}\text { electric } \\
\text { reisistance }\end{array}$ & $\begin{array}{l}\text { aperture tube, } \\
\text { electrode }\end{array}$ & 0 & $\times$ & $\times$ & $\times$ \\
\hline
\end{tabular}

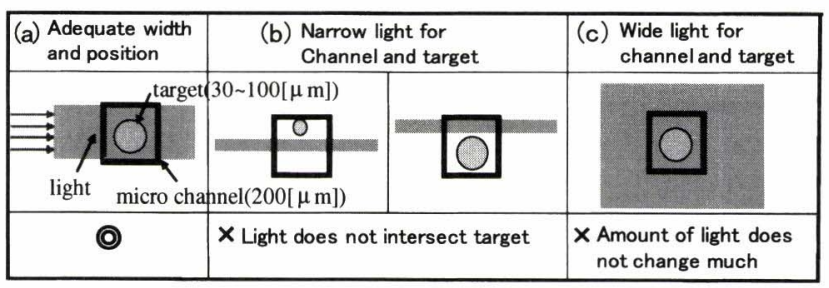

Fig. 1 Adequate light width for channel and target

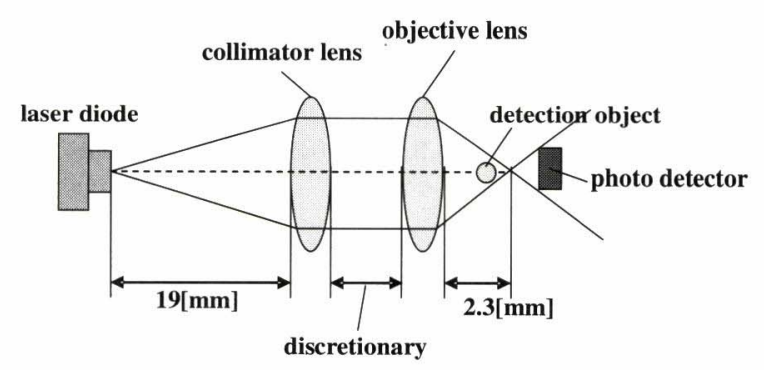

Fig. 2 Layout of lens and laserdiode

が流路幅より太く, 受光素子も流路幅より大きい場合, 光量の 変化が十分得られずに細胞を検知できない場合がある。よって, Fig. 1 (a)のように照射光が流路幅を過不足なく覆う必要がある.

\section{3 センサ基本構成}

光遮断法によるセンサの基本構成は, 発光素子と受光素子で ある. 発光素子には, 安価で小型の半導体レーザダイオードを 用いる.流路の材料である PDMS の紫外一可視光領域に扔け る光吸収特性は, 可視光領域での吸光度が最も低いことが知ら れている．また，検出対象である生体細胞に影響が少ないのは 近赤外光である. これらを考慮し, 本研究では赤色レーザダイ オードを光源として用いることとした。レーザダイオードから 発振された光を集光するために, コリメータレンズと対物レン ズを使用する．レンズ系のレイアウトを Fig. 2 に示す.

\section{4 レーザヘッドの試作}

2.3 節で述べた構成に基づき，レーザヘッドを試作した。レー ザダイオードとして三菱製半導体レーザ三菱電機製 ML120G20, レンズは DVD 用非球面レンズを用いた，全体の大きさは直径 $11[\mathrm{~mm}]$, 高さ $27[\mathrm{~mm}]$ である. 試作したレーザヘッドの概略 戝と概観写真をそれぞれFig. 3, Fig. 4 に, また, レンズの仕 


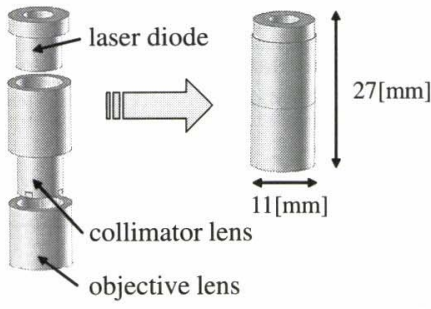

Fig. 3 Prototype laserhead

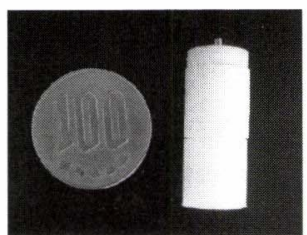

Fig. 4 Photograph of prototype laserhead

Table 2 Specification of lens

\begin{tabular}{|c|c|c|}
\hline item & objective lens & collimator lens \\
\hline Numerical Aperture(NA) & 0.6 & 0.118 \\
\hline focal length & $3.6[\mathrm{~mm}]$ & $21.6[\mathrm{~mm}]$ \\
\hline design wavelength & $635[\mathrm{~nm}]$ & $635[\mathrm{~mm}]$ \\
\hline outer diameter & $\phi 5.6[\mathrm{~mm}]$ & $\phi 6.4[\mathrm{~mm}]$ \\
\hline center thickness & $2.75[\mathrm{~mm}]$ & $3.6[\mathrm{~mm}]$ \\
\hline effective aperture & $4.32[\mathrm{~mm}]$ & $5.12[\mathrm{~mm}]$ \\
\hline
\end{tabular}

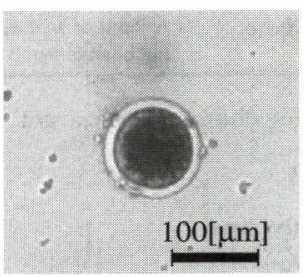

(a)

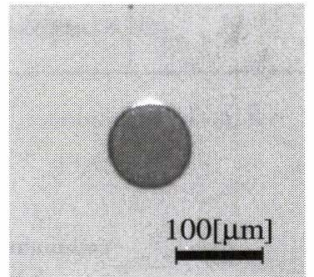

(b)

Fig. 5 Egg cell ((b) after removing zona pellucida)

様を Table 2 に示す。レンズの焦点深度は約 $\pm 0.9[\mu \mathrm{m}]$, 最 小スポット径は約 $1[\mu \mathrm{m}]\left(1 / e^{2}\right)$ である。ただし, 本論文で計 測対象としている細胞のサイズは 80〜100 $[\mu \mathrm{m}]$ であり数 $[\mu \mathrm{m}]$ オーダでレーザを集光させる必要はない。実際のスポット径は 対物レンズと細胞との距離によって変わるので, 細胞のサイズ に応じてレーザヘッドの位置を調整することでスポット径を変 更可能である.

\section{3. 細胞検出基礎実験}

\section{1 検出対象細胞}

本実験では，検出対象細胞としてウシの未受精卵を培養成熟 させたものを用いることとする。未受精卵は透明帯という弾力 性のある夕ンパク質の外款に覆われている（Fig.5 (a)）が，こ の透明膜を除去した卵子 (Fig. 5 (b)) と，ささらに透明帯除去卵 子を半分に切断した卵子を用いる。透明帯除去卵子の直径は約 $100[\mu \mathrm{m}]$ である.

\section{2 実験システム}

実験システムを Fig. 6 に示す. 流路チップは顕微鏡下に設 置し，受光素子はチップに直接貼付する。レーザヘッドは微動 ステージ $(X-Y-Z)$ に固定する. 受光素子の出力はアン プにより増幅させ PC に取り达む。流路は幅 $200[\mu \mathrm{m}]$, 深さ $117.33[\mu \mathrm{m}]$ である. 受光素子の感光面は $1.1 \times 1.1\left[\mathrm{~mm}^{2}\right]$ で, 流路幅 $200[\mu \mathrm{m}]$ より大きいため, 周囲の光を遮断するマスクを 設置する，不透明なシールを用いて流路上の $200[\mu \mathrm{m}]$ の幅を空 けてその両側をマスクし, 受光素子が流路上の光だけを受光す

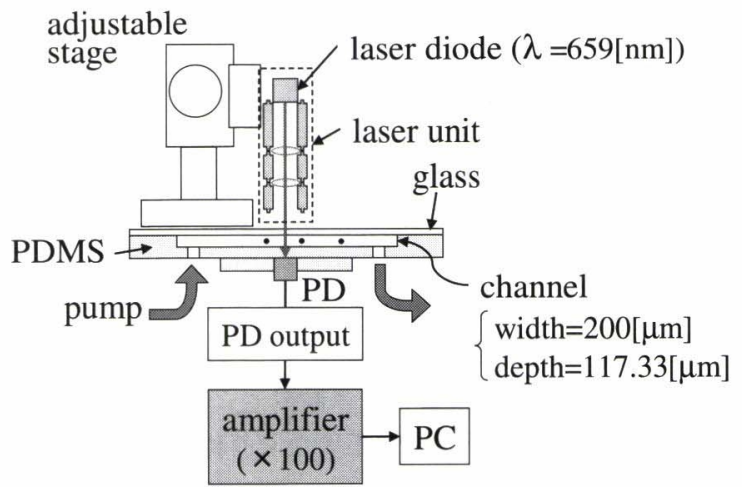

Fig. 6 Schematic diagram of experiment system

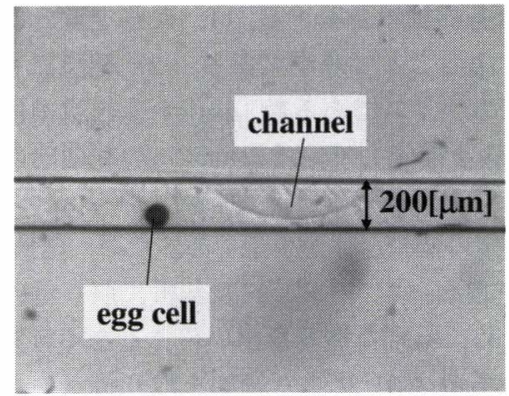

Fig. 7 Picture of egg cell in micro channel

\section{るようにする。}

\section{3 実験手順}

細胞検出実験の実験手順は以下の通りである.

(1) チップ作製

(2) 卵子の透明帯除去および切断

(3) 受光素子の設置

受光素子の感光面を流路に合わせて設置する.

(4) マスク貼付

（5）流路への細胞の導入

ポンプで㓌圧を加えてシャーレ内の卵子を流路内まで吸引 する。このとき，顕微鏡で吸引口を観察しながら，細胞が 確実に流路内に入っていることを確認する（Fig. 7）.

（6）光源の位置合わせ

微動ステージに固定したレーザヘッドの位置合わせを行う. スリットを貼付しているので，受光素子の出力電圧を観察 し, 出力が最大となる位置で実験を行う.

(7) 計測開始

ポンプの送流方向を切り替え, 細胞を流路内で往復させて 繰り返し計測を行う。

\section{4 実験}

ポンプの流量を $1.0[\mu \mathrm{l} / \mathrm{min}], 2.0[\mu \mathrm{l} / \mathrm{min}], 4.0[\mu \mathrm{l} / \mathrm{min}]$, $8.0[\mu \mathrm{l} / \mathrm{min}]$ の 4 段階に設定し, 実験を行った.

\section{5 実験結果}

ポンプの流量を $1.0[\mu \mathrm{l} / \mathrm{min}], 2.0[\mu \mathrm{l} / \mathrm{min}], 4.0[\mu \mathrm{l} / \mathrm{min}]$, $8.0[\mu \mathrm{l} / \mathrm{min}]$ の各場合にそれぞれ 10 回, 4 回, 2 回, 1 回の 合計 17 回の計測を行い, 細胞通過の際の発生パルスをすべて確 認することができた。すべての計測において用いた細胞は，同 


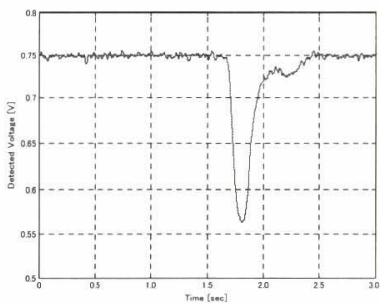

(a)

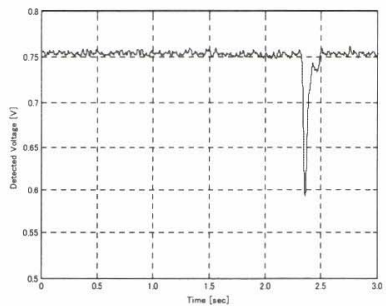

(c)

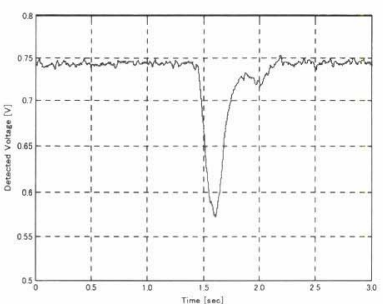

(b)

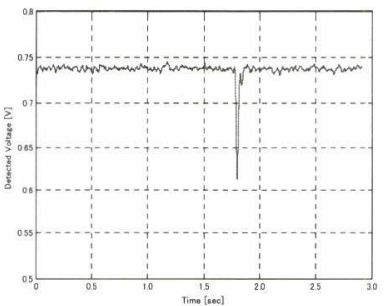

(d)
Fig. 8 Detected Voltage ((a): flow speed $=0.710[\mathrm{~mm} / \mathrm{s}], \quad(b)$ : $1.420[\mathrm{~mm} / \mathrm{s}],(\mathrm{c}): 2.841[\mathrm{~mm} / \mathrm{s}],(\mathrm{d}): 5.682[\mathrm{~mm} / \mathrm{s}])$

Table 3 Pulse width

\begin{tabular}{|l||c|c|c|c|}
\hline Flow volume of pump $[\mu \mathrm{l} / \mathrm{min}]$ & 1.0 & 2.0 & 4.0 & 8.0 \\
\hline Calculated flow speed $[\mathrm{mm} / \mathrm{sec}]$ & 0.71 & 1.42 & 2.84 & 5.68 \\
\hline Measurement pulse width $[\mathrm{sec}]$ & 0.74 & 0.63 & 0.16 & 0.07 \\
\hline Estimated cell speed $[\mathrm{mm} / \mathrm{sec}]$ & 0.41 & 0.48 & 1.88 & 4.6 \\
\hline
\end{tabular}

一の個体である. 各流速における受光素子の出力電圧のグラフ をFig. 8 に示す.すべてのデータの $\mathrm{S} / \mathrm{N}$ 比を計算すると, 平 均 $21.5[\mathrm{~dB}]$ である. また, 流速の変化による電圧変位のピー ク值変動は見られない。

Table 3 にポンプ流量と流路断面積から算出した流路内流速 と, パルス幅の測定值, 測定值から推定した細胞の移動速度を 示す。この実験では正確な細胞の移動速度を求めることは目的 ではないが, Table 3 の細胞の移動速度は, 受光素子が感光で きる面の直径が少なくとも流路幅の $200[\mu \mathrm{m}]$ あることと, 細胞 の直径は $100[\mu \mathrm{m}]$ であることを仮定して得られる最小の移動速 度で見積もった值である. 流路内に拈ける細胞の移動速度の推 定は容易でない要因の一つとして，マイクロな系（1 [ mm] 程度 以下）では粘性力が支配的になる [8]ことが挙げられる．粘性力 が支配的になることにより, 細胞と流路内側との間に生じる表 面力が細胞の移動を妨げる方向に働き，ポンプ流量と流路断面 積から算出される流路内流速よりも, パルス幅から推定した細 胞の移動速度が小さくなることが推測される.

実験では, 4 段階のポンプ流量のいずれにおいても, 確実に 細胞が検出されることが確認できた，最小に見積もった細胞の 移動速度が $1,000[\mu \mathrm{m} / \mathrm{s}]$ 以上の場合に細胞が検出できているこ とから目標としている細胞の移動速度 $1,000[\mu \mathrm{m} / \mathrm{s}]$ で確実に検 出できることが達成できている。よって, 本実験より, 七ンサ の基本構成は妥当であり, 細胞を十分検出できるということが 分かった。

\section{4. 細胞検出センサの実装}

本研究で提案するセンサは, 小型でかつ細胞との親和性が重

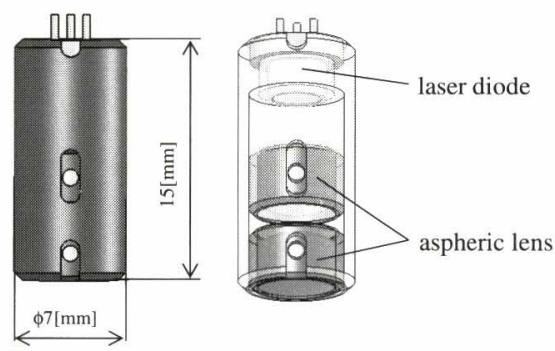

Fig. 9 New prototype laserhead

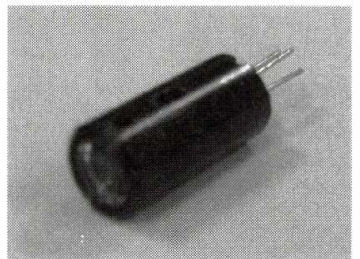

Fig. 10 Picture of new prototype laserhead

Table 4 Specification of aspheric lens

\begin{tabular}{|l||c|}
\hline item & specification \\
\hline Numerical Aperture(NA) & 0.3 \\
\hline focal length & $6.16[\mathrm{~mm}]$ \\
\hline desing wavelength & $780[\mathrm{~nm}]$ \\
\hline outer diameter & $4.7[\mathrm{~mm}]$ \\
\hline center thickness & $3.48[\mathrm{~mm}]$ \\
\hline effective aperture & $3.7[\mathrm{~mm}]$ \\
\hline
\end{tabular}

要であることは言及してきた。この章では，本センサのもう一 つの重要な要素である「特殊装置を用いない実装」を実現する 方法について述べる。

\section{1 レーザヘッドの改良試作}

3 章より, センサの検出機構の有効性を実証することができ た.ヘッドを小型にするため,レンズは Edmund Optics 製非球 面レンズ 90899-H を使用することとする，改良試作したレーザ ヘッドの概要罒と概観写真をそれぞれ Fig. 9, Fig. 10 に示す. ヘッドの直径は $7[\mathrm{~mm}]$, 高さは $15[\mathrm{~mm}]$ である. 使用したレン ズの仕様を Table 4 に示す.レンズの焦点深度は約 $\pm 3.6[\mu \mathrm{m}]$, 最小スポット径は約 $2[\mu \mathrm{m}]\left(1 / e^{2}\right)$ である.

\section{2 検証実験}

透明带除去卵子 (Fig. 5 (b)) と, それをさらに二つに切断し た卵子について同条件下で検出実験を行い, その出力信号を比 較する.ポンプ流量は $2.0[\mu \mathrm{l} / \mathrm{min}]$ とした. 切断前と切断後の 細胞でそれぞれ 50 回ずつ計測実験を行い, すべて検出に成功 した. 実験結果を Fig. 11 に示す.

また，それぞれの変化率の平均值と標準偏差を Table 5 に 示す.これより, 卵子の大きさに出力電圧の変化率が依存して いることが分かる.このことから, 出力電圧の変化率から細胞 の大きさの判別が可能であると思われる.

流路内に細胞以外の微小な浮遊物などがある場合にも出力電 圧は変化するが, 対象とする細胞の大きさと比較し浮遊物が微 小な場合には出力電圧の変化も小さくなることから, 細胞と微 小浮遊物との区別は可能となる. 


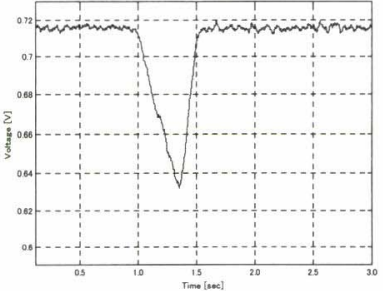

(a)

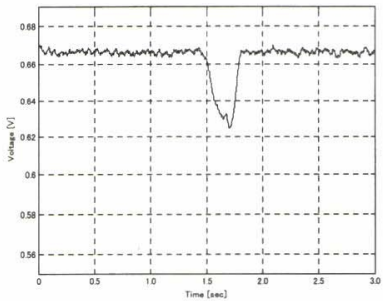

(c)

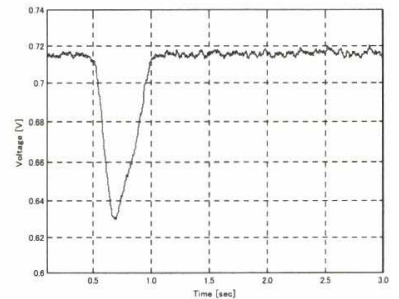

(b)

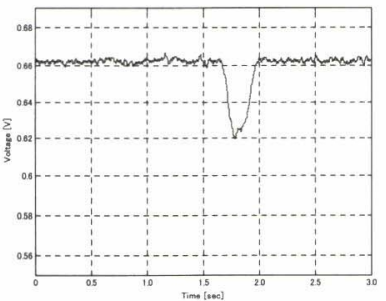

(d)

Fig. 11 Detected Voltage ((a), (b): $\phi 100[\mu \mathrm{m}],(\mathrm{c}),(\mathrm{d}): \phi 80[\mu \mathrm{m}])$

Table 5 Rate of voltage change

\begin{tabular}{|c||c|c|}
\hline size & $100[\mu \mathrm{m}]$ & $80[\mu \mathrm{m}]$ \\
\hline average & $116[\mathrm{mV}]$ & $64.8[\mathrm{mV}]$ \\
\hline standard deviation & $7.23[\mathrm{mV}]$ & $7.26[\mathrm{mV}]$ \\
\hline
\end{tabular}
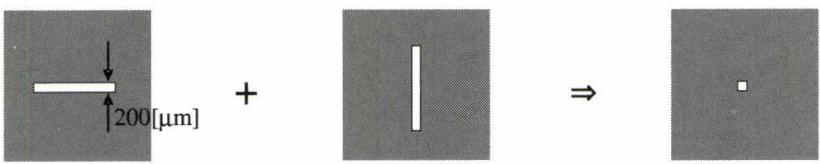

Fig. 12 Slit mask

\section{3 検出アルゴリズム}

受光素子の出力電圧を入力信号とし, ローパスフィルタをかけ て雑音を除去した後，ある閾值よりも変化の割合が大きい場合 に細胞が通過したものと判断し, その結果を出力する。ローパス フィルタのサンプリング周波数は $1[\mathrm{kHz}]$, 遮断帯域は $50[\mathrm{~Hz}]$ である.

\section{4 センサのアライメント法}

本研究で開発してきたセンサで最も重要かつ困難なのは, 細 胞通過による光量の変化を確実に検出するための光源・流路 · 受光素子の位置合わせ（光軸合わせ）である．これを解決する ため, レーザの光を流路の幅に合わせて過不足なく当てるため にスリットがついたマスクを用いることを提案する。マスクは, $200[\mu \mathrm{m}]$ のスリットが入った薄板を 2 枚用意する。まず流路と平 行に 1 枚設置し, もう 1 枚を 90 度回転させて重ねる.最終的に $200 \times 200\left[\mu \mathrm{m}^{2}\right]$ の正方形のアパーチャを形成する (Fig. 12). このマスクにより, 受光素子の感光面を限定することができ, 流 路の幅に合わせて過不足なく光を当てることができる.さらに， レーザヘッドの位置合わせも簡便になる。

このマスクを利用して, Fig. 13 に示すアライメント法を提 案する.アライメントの基準をすべて同じ大きさの正方形とし， 正方形の中心を光軸として設定する。レーザヘッド，マスクは この基準の正方形と同じ大きさになるようにあらかじめ加工し ておく、レーザヘッド，2 枚のマスクをマスクの外周の正方形

新井健生井上健司山田真人

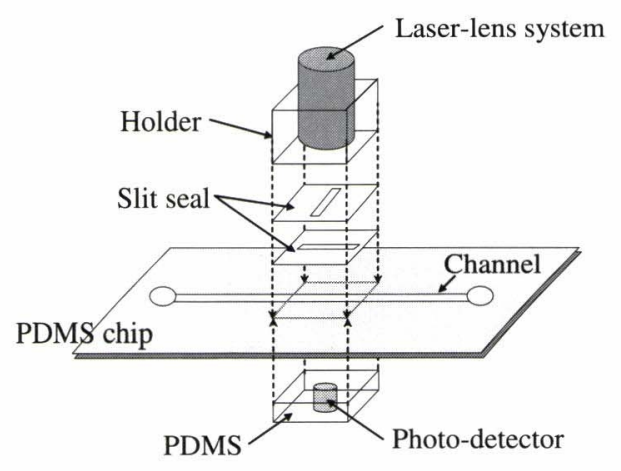

Fig. 13 Alignment of sensor

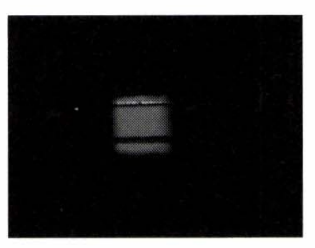

Fig. 14 Aperture composed of two masks with slit

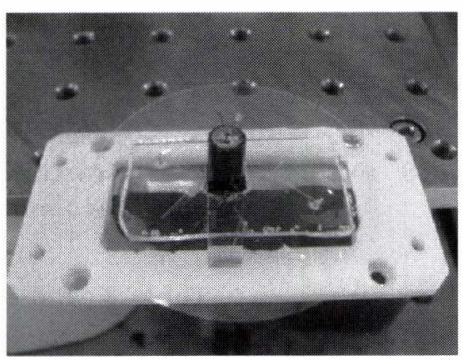

Fig. 15 PDMS chip with cell detection sensor
を合わせて配置することによって，レーザの光軸も簡便に位置 合わせすることができる.

2 枚の薄板のスリットを交差させて構成したアパーチャを Fig. 14 に示す。スリットを交差させて構成されたアパーチャ から，流路が見えていることが確認できる.PDMS チップにセ ンサを実装し一体化したチップを Fig. 15 に示す. Fig. 15 に実 装しているレーザヘッドは Fig. 9, Fig. 10 に示したレーザヘッ ドのレンズを 1 枚にし, 高さを $11[\mathrm{~mm}]$ に小型化したものであ る。流路上にアパーチャを正確に配置することによって, 光を 過不足なく流路に当てることが可能となり，その結果センサ全 体の小型化も実現している.

\section{5. 結言}

本論文では，モジュール基板上の微小流路内を移動する細胞 を検出するセンサの構成法を提案し, 細胞検出実験, センサの実 装法について述べた. 計測対象が生きた細胞であり, ディスポー ザル性と細胞との親和性が求められることから, 細胞と接触す る流路の素材としてシリコンゴムの一種である PDMS（polydimethylsiloxane）を選定した。 センサは, 光遮断法に基づき レーザヘッドと検出器を組み合わせて光学系を構成し, PDMS チップ内の微小流路上に配置する. 微小流路内を移動する直径 $100[\mu \mathrm{m}], 80[\mu \mathrm{m}]$ のウシの卵細胞を検出する実験を行い, 提 案するセンサを用いて確実に検出できることを示した。さらに， センサを微小流路上に正確に位置合わせして配置する簡便な実 装方法を提案し, センサの PDMS チップへの実装を行った.

謝 辞 本研究は生研センター異分野融合研究事業の助成を 得て行われたものである. 


\section{参 考 文 献}

[1] 新井健生, 谷川民生, 新井史人, 佐藤理, 麻生博, 高橋清也: “マイ クロロボティクスを適用した胚操作の自動化”, 第 24 回日本ロボッ 卜学会学術講演会予稿集 CD-ROM, 3L11, 2006.

[2] Z. Wang, J. El-Ali, I.R. Perch-Nielsen, K.B. Mogensen, D. Snakenborg, J.P. Kutter and A. Wolff: "Microchip Flow Cytometer with Integrated Polymer Optical Elements for Measurement of Scattered Light," Proceedings of 17th IEEE International Conference on Micro Electro Mechanical Systems, pp.367-370, 2004.

[ 3 ] 漆畑晋一: “粒子カウンタ $\mathrm{WP} 402 \mathrm{G}$ ”, 横河技報, vol.44, no.2, pp.77$80,2000$.

[4] Y. Xia and G.M. Whitesides: "Softlithographie," Angew. Chem., vol.110, pp.568-594, 1998.
[ 5 ] J.L. Wilbur, A. Kumar, E. Kim and G.M. Whitesides: "Microfabrication by Microcontact Printing of Self-Assembled Monolayers," Advanced Materials, vol.6, pp.600-604, 1994.

[6] E. Delamarche, A. Bernard, H. Schmid, B. Michel and H. Biebuyck: "Patterned Delivery of Immunoglobulins to Surfaces Using Microfluidic Networks," Science, vol.276, no.5313, pp.779-781, 1997.

[7] E. Delamarche, H. Schmid, A. Bietsch, N.B. Larsen, H. Rothuizen, B. Michel and H. Biebuyck: "Transport Mechanisms of Alkanethiols during Microcontact Printing on Gold," J. Phys. Chem. B, vol.102, no.18, pp.3324-3334, 1998.

[8] マイクロマシン技術総覽編集委員会編：マイクロマシン技術総覽一ナ ノテクノロジーの基盤技術一. 第 4 節, 産業技術サービスセンター, 2003.

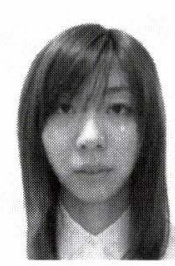

藤本香織 (Kaori Fujimoto)

2005 年 3 月大阪大学基礎工学部システム科学科卒 業, 2007 年 3 月同大学大学院基礎工学研究科シス テム創成専攻博士前期課程修了. 同年, シャープ株 式会社入社. 在学中, マイクロロボティクスを適用 した胚操作の自動化に関する研究に従事.

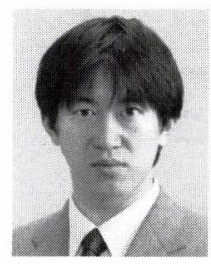

前 泰志 (Yasushi Mae)

1998 年大阪大学大学院工学研究科電子制御機械工 学専攻博士課程修了, 博士 (工学). 同年, 同大学 大学院基礎工学研究科助手. 2004 年福井大学工学 部助教授. 2007 年 6 月より大阪大学大学院基礎工 学研究科准教授となり現在に至る。ロボットビジョ ン, 環境知能化, 作業移動型ロボット等の研究に従 事. 日本機械学会, 情報処理学会, 電子情報通信学会, 日本バーチャ ルリアリティ学会, IEEEの会員.

(日本ロボット学会正会員)

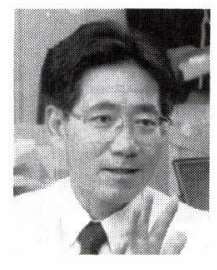

新井健生（Tatsuo Arai）

1977 年東京大学大学院工学系修士課程修了. 工業 技術院機械技術研究所を経て, 現在大阪大学大学院 基礎工学研究科教授. パラレルメカニズム, マイク ロマニピュレーション, 作業移動型ロボット等の研 究に従事. 1986 1987 年 MIT 客員研究員. 日本 機械学会, 計測自動制御学会, IEEE 等の会員.

(日本ロボット学会正会員)

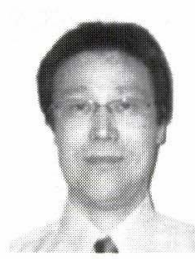

山田真人 (Masato Yamada)

1986 年岐皁大学大学院工学研究科修士課程修了. 同年三洋電機株式会社入社. 画像読み取り装置, 光 ディスク用光学ヘッド，レーザ距離センサ等の研究 に従事. 計測自動制御学会, 精密工学会, IEEE 会 員.

(日本ロボット学会正会員)

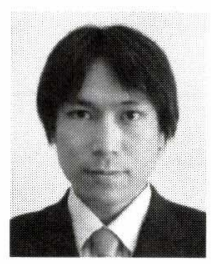

國松禎明（Sadaaki Kunimatsu）

1999 年大阪大学基礎工学部システム工学科卒業, 2005 年同大学院基礎工学研究科システム人間系専 攻博士後期課程修了, 博士 (工学). 同年, 同大学 院基礎工学研究科特任研究員, 2007 年熊本大学大 学院自然科学研究科助教となり, 現在に至る. シス テム制御工学とその応用に関する研究などに従事. 計測自動制御学会などの会員.

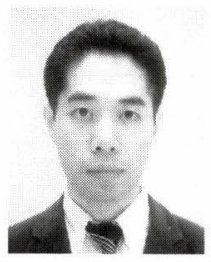

田窪朋仁 (Tomohito Takubo)

2003 年 3 月筑波大学大学院工学研究科博士課程修 了. 博士 (工学). 同年 4 月大阪大学大学院基礎工 学研究科特任研究員, 2004 年 7 月大阪大学大学院 基礎工学研究科助手. 2006 年 4 月大阪大学大学院 基礎工学研究科助教. ヒューマノイドロボット, 作 業移動型ロボット，人間—ロボット協調システムの 研究に従事. 日本機械学会等の会員.

(日本ロボット学会正会員)

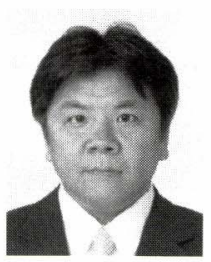

井上健司（Kenji Inoue）

1988 年東京大学大学院工学系研究科修士課程修了. 同年東京大学助手. 大阪大学助手, 講師, 助教授を 経て, 2007 年山形大学大学院理工学研究科教授と なり現在に至る。ハプティック・デバイス，作業移 動型ロボット, マイクロマニピュレーションなどの 研究に従事. 博士 (工学)。日本機械学会, 計測自 動制御学会, 日本バーチャルリアリティ学会の会員.

(日本ロボット学会正会員) 